Ks. Slawomir Kunka*

Katolicki Uniwersytet Lubelski Jana Pawła II

\title{
REPERKUSJE TRAKTATU O STWORZENIU W CALOŚCI TEOLOGII
}

Co by było, gdyby nie było Boga? Z pewnością wielu uzna to pytanie za nonsens. Jednak głębsza refleksja pozwoli zobaczyć, że jest ono bardzo sensowne. W pytaniu tym jest bowiem ukryta doniosła świadomość teologicznej struktury rzeczywistości. Może ono nawet okazać się bardzo pomocne w ukazaniu wszelkich „reperkusji traktatu o stworzeniu w całej teologii”. Na wskazane pytanie nie sposób odpowiedzieć bez pytania pomocniczego. W wersji kosmologicznej brzmi ono: „kim jest Bóg wobec swego stworzenia?”. W wersji zaś antropologicznej: „kim jest Bóg dla człowieka?” lub: „co leży u podstaw ich wzajemnego «zainteresowania» sobą?".

\section{WSTĘP: STAN OSKARŻENIA I OBROŃCA. TEOLOGIA A SPRAWA CZŁOWIEKA}

W historii filozofii i teologii przyjęło się usprawiedliwianie istnienia Boga przed człowiekiem. Tak można określić podstawowe zadanie teodycei. Czy jednak ujęcie to jest jedynie właściwym? Czy współczesne wołanie o dalej posunięty krytycyzm w myśleniu, zgoda na nowe rozwiązania w kwestiach najbardziej fundamentalnych i ważnych nie domaga się, aby stworzenia i Stwórca zmienili miejsca w sali intelektualnych rozpraw? Rozprawy, o których tu mowa, trwają już całe wieki, a dotyczą zarzutu wobec Boga, że nie istnieje, albo że istnieje inaczej, niż by człowiek mógł tego od Niego oczekiwać. Sprawa ta sięga początków historii człowieka, a nawet o czym podpowiada nam objawienie - „czasów ponadhistorycznych” Adama i jego żony. Nie oni wnieśli to oskarżenie, ale przystali na nie (por. Rdz 3). Czas już zatem na zmianę miejsc w sali dziejowej rozprawy między Stwórcą a stworzeniem.

\footnotetext{
${ }^{*}$ Ks. Sławomir Kunka, kapłan diecezji pelplińskiej, dr teologii, adiunkt Katedry Historii Dogmatów w Instytucie Teologii Dogmatycznej KUL, wykładowca teologii dogmatycznej w WSD w Kielcach, Lublinie i Pelplinie.
} 
W optyce współczesnych nurtów myślowych, takich jak np. ideologia gender ${ }^{1}$, może nawet okazać się, że nastąpiła już zmiana miejsc. Wystarczy więc, że człowiek ją sobie tylko uświadomi i odnajdzie się na swoim nowym miejscu. Wydaje się bowiem, że miejsce dawnej teodycei wyparła współcześnie potrzeba antropodycei ${ }^{2}$. Jak to rozumieć? Dla bacznego i krytycznie myślącego obserwatora współczesnych nurtów filozoficznych i antypedagogicznych procesów społecznych nie będzie to trudne do uzasadnienia. Człowiek bowiem, w sali intelektualnych rozpraw poniekąd zamienił się miejscami ze swoim Stwórcą. Pewnie nawet nie zrobił tego świadomie. Chcąc przejąć kompetencje Stwórcy dotyczące określania granicy dobra i zła oraz władzy nad życiem stworzeń (por. Rdz 3,5), człowiek usiadł (czy może nawet: posadzit się) niepostrzeżenie także zamiast Boga na ławie oskarżonych. Teraz jego istnienie bądź sposób jego istnienia trzeba będzie usprawiedliwić przed nim samym. Człowiek bowiem, zajmując teodycealne miejsce Boga, nie zrezygnował z roli oskarżyciela ${ }^{3}$. Czyż tak się nie dzieje współcześnie? Przecież dziś człowiek wydaje się już prawie niezdolnym do tego, aby zrozumieć własną wartość. Pewnie trzeba wyraźniej powiedzieć: konkretny współczesny człowiek chce szacunku dla siebie, swoich przekonań, uznania swego światopoglądu, przestrzegania swoich praw i wolności. Zapomina jednak, że obok żyje ktoś inny. Może jeszcze w odmiennym stanie, może z niepełnosprawnością, może słabszy, chory, w podeszłym wieku. On też ma prawo żyć. On też ma swoją godność. To także człowiek.

Gdzie teraz jest Bóg? Gdzie obecnie zasiada w sali rozpraw? Wspomniana zamiana miejsc nie pozbawiła Boga roli oskarżonego. Bóg wciąż, szukając człowieka (por. Rdz 3,9), siedzi teraz na ławie oskarżonych razem z nim. Może tylko oskarżyciel nie zwraca na Niego uwagi z takim natężeniem jak w dobie teodycei. Słowa tragicznego rzymskiego proroka wypowiedziane wobec Syna Bożego w dniu Jego sądu są tego wciąż aktualnym potwierdzeniem: „Oto człowiek” (J 19,5). Zatem teraz człowiek i jego Bóg dzielą los oskarżonych. Kto zatem pełni rolę obrońcy? Człowiek zajmuje dwa pozostałe miejsca - nic więc dziwnego, że ta rola nie może być przez niego spełniona. Jak jeszcze $\mathrm{w}$ dobie teodycei człowiek próbował bronić Boga przed człowiekiem, tak w dobie antropodycei jest to już absolutnie niemożliwe. W nowej obsadzie miejsc już tylko sam Bóg może spełnić rolę obrońcy. Tylko On bowiem zna oskarżanego (por. J 2,25), bo był zanim

\footnotetext{
${ }^{1}$ Por. H.B. Gerl-Falkovitz, Różnice ptciowe. Krytyczne pytania pod adresem ,,gender studies", w: Kobiety w Chrystusie. W stronę nowego feminizmu, red. M.M. Schumacher, thum. M. Romanek, Warszawa 2008, s. 80-96; B. V. Coles, Nowy feminizm. Powtórne połaczenie ptci biologicznej $i$ ptci spoleczno-kulturowej, w: Kobiety w Chrystusie, dz. cyt., s. 139-157; L. Scaraffia, Równość spoleczna a ideologia , gender”, „L'Osservatore Romano” (wyd. pol.) 4(2011), s. 50-53.

${ }^{2}$ Por. A. Gesché, Człowiek, thum. A. Kuryś, Poznań 2005, s. 109.

${ }^{3}$ Rola oskarżyciela nie jest pierwotnie rolą człowieka. Człowiek przejął ją od kogoś bardzo innego (por. Rdz 3,1.5; Ap 12,10; Cz.S. Bartnik, Dogmatyka katolicka, t. I, Lublin 2000, s. 465).
} 
człowiek „stał się” (por. J 1,1; 8,58; Kol 1,17). Tylko Stwórca może zająć miejsce obrońcy sprawy człowieka i świata.

Cały ciężar refleksji teologicznej spoczywa między rzeczywistością Boga a rzeczywistością człowieka, który przyjmuje Boże objawienie. Człowiek bez Boga nie zrozumie siebie. Nie skorzysta z pełni wlasnych ontologicznych preferencji, jeśli odrzuci fakt swej „stworzoności”, czyli źródłowego i celowego odniesienia do Boga. Tylko bowiem Stwórca może usprawiedliwić fakt istnienia stworzeń. Tylko Bóg może usprawiedliwić człowieka - nie tylko od jego winy (soteriologia), lecz też fakt, że człowiek w ogóle istnieje i to, kim on jest (protologia). Nie jest zatem przesadą twierdzenie, że kto ogranicza się w teologii tylko do dogmatu stworzenia, zatrzymuje się w połowie drogi. Kto natomiast nie docenia dogmatu stworzenia, ten nic nie rozumie.

Teologia ma za zadanie analizować treści objawione przez Boga i wyciągać z nich wnioski nie tylko teoretyczne, ale też praktyczne. Wiemy przecież, że treścią Bożego objawienia nie jest to, co Pan Bóg wie, lecz to, co człowiek musi wiedzieć, aby Boga odnaleźć i wybrać właściwą drogę do swojej ojczyzny (por. Flp 3,20). Katechizm Kościoła Katolickiego stwierdza, że „tajemnica Trójcy Świętej stanowi centrum wiary i życia chrześcijańskiego”. Jest ona „źródłem wszystkich innych tajemnic wiary oraz światłem, które je oświeca"4. Dlatego naukę o początkach stworzenia, określaną jako protologia, należy postrzegać jako dogmatyczne „rozwinięcie wyznania wiary w Trójcę Świętą" . Rzeczywistość Trójcy Świętej jest bowiem prawdą centralną, podstawową i źródłową dla innych zagadnień dogmatycznych.

W stworzeniu ma swój początek zbawczy zamysł Boga. W nim ma swoje korzenie cała historia zbawienia, która prowadzi do Chrystusa, Bożego Syna i „Pierworodnego wobec każdego stworzenia” (Kol 1,15). Z drugiej strony należy zauważyć, że to „misterium Chrystusa jest decydującym światłem oświecającym tajemnicę stworzenia”. Chrystus objawia cel powołania świata, a szczególnie człowieka, do istnienia. „Od początku Bóg miał na względzie chwałę nowego stworzenia w Chrystusie (por. Rz 8, 18-23)",

W niniejszym opracowaniu za cel przyjmuje się analizę „reperkusji traktatu o stworzeniu" w wybranych aspektach teologicznych. Każdy z tych aspektów, które dotyczą odpowiednio kolejnych Osób Boski, dzieła Odkupienia, antropologii teologicznej i eschatologii, został nazwany Ewangelia, czyli Dobra Nowina ${ }^{7}$.

${ }^{4}$ Katechizm Kościoła Katolickiego, nr 234.

${ }^{5}$ M. Kowalczyk, Traktat o stworzeniu, w: Dogmatyka, t. VI, red. E. Adamiak $\mathrm{i}$ in., Warszawa 2007, s. 17.

${ }^{6}$ Katechizm Kościoła Katolickiego, nr 280.

${ }^{7}$ Por. S. Kunka, Ewangelia ludzkiej cielesności, „Roczniki Teologii Dogmatycznej” 58(2011), t. 3, s. 81-97. 


\section{EWANGELIA O OJCU. ŹRÓDŁO ISTNIENIA}

„Jest jeden Bóg”. Ten jeden Bóg stworzył świat, i choć świat nie jest boski, to jest Boży. Jest dziełem Boga, należy do Niego. Prostym wnioskiem płynącym z przyjętego przez teologię założenia, że stworzenie zostało dokonane ex nihilo ${ }^{8}$, jest prawda, że wszystko, co istnieje, ma swe źródło w Bogu, w Jego miłości. Bóg przecież nie potrzebował stworzenia dla siebie samego. Stworzył świat, bo jest Miłością, a nie dlatego, że musial ${ }^{9}$. Gdyby tej miłości Stwórcy zabrakło, nic by nie miało ani mocy, ani powodu, aby zaistnieć i trwać. Cały świat jest przeniknięty miłością, która go zawsze będzie przewyższać, bo jest miłością Boga. W tajemnicy stworzenia zawarte jest „promieniowanie miłości”, dlatego jest ono darem. Cały akt powoływania do istnienia został oparty na „hermeneutyce daru”. Opiera się ona na miłości, która po pierwsze obdarzając istnieniem, sprawia byty, a następnie tymi bytami obdarza inne stworzenia. Ostatecznie wszystko zmierza ku człowiekowi. „Tylko miłość stwarza dobro i tylko ona pozwala się ostatecznie dostrzec poprzez wszystkie jego wymiary i profile w stworzeniu, a zwłaszcza w człowieku" ${ }^{\prime 0}$. Bóg obdarzać może tylko dobrem, a stworzenie jest „dobre” - odniesione do człowieka, brane z nim jako całość, jest „bardzo dobre” (Rdz 1,31). Jest więc stworzenie ,chciane przez Boga jako dar skierowany do człowieka, jako dziedzictwo, które jest przeznaczone dla niego i powierzone mu" ${ }^{\prime 1}$. Biorąc pod uwagę fakt, że człowiekowi z racji przygodności istnienie nie przysługuje w sposób konieczny, można się nawet zgodzić, że stworzenie jest owocem miłosierdzia Bożego ${ }^{12}$.

Istnienie jest wartością, która przewyższa zdolności ludzkiego działania, ludzkiej tylko decyzji. To jeszcze bardziej powinno uświadomić człowiekowi, że został powołany do istnienia ,z nadmiaru [...] miłości i dla miłości” ${ }^{13}$. Stwarzając, Bóg wypowiada swoje „tak” wobec życia przygodnego ${ }^{14}$. Z tego stwórczego fiat wiara chrześcijańska obiera swe ukierunkowanie „ku życiu” oraz ,afirmuje życie na wszystkich jego poziomach jako

${ }^{8}$ Por. Katechizm Kościoła Katolickiego, nr 296-298 oraz A. Maryniarczyk, Creatio ex nihilo, w: Powszechna Encyklopedia Filozofii, t. II (C-D), Lublin 2001, s. 306-318.

${ }^{9}$ Por. Katechizm Kościoła Katolickiego, nr 295: „Świat nie powstał w wyniku jakiejś konieczności, ślepego przeznaczenia czy przypadku".

${ }^{10} \mathrm{~J}$ an Paweł II, Mężczyzna i niewiasta stworzyt ich. Odkupienie ciała a sakramentalność malżeństwa, red. T. Styczeń, Lublin 2008, s. 53.

${ }^{11}$ Katechizm Kościoła Katolickiego, nr 299. Prawdą jest, że „Kościół musiał wielokrotnie bronić prawdy o dobroci stworzenia, w tym także świata materialnego" (tamże).

${ }^{12}$ Św. Faustyna M. Kowalska pisze w swoim Dzienniczku: „Miłosierdzie Boże, w powołaniu nas z nicości do bytu, ufamy Tobie" (taż, Dzienniczek. Miłosierdzie Boże w duszy mojej, wyd. VIII, Warszawa 1999, nr 949).

${ }^{13}$ W. Półtaw ska, Ptciowość w ujęciu Karola Wojtyty, w: Naturalne planowanie rodziny w ujęciu wybranych dyscyplin naukowych, red. W. Wieczorek i in., Lublin 2008, s. 41.

${ }^{14}$ Por. Jan Paweł II, Stworzenie: Bóg powoluje z nicości do istnienia świat i człowieka, nr 2, w: Katechezy Ojca Świętego Jana Pawła II. Bóg Ojciec, Kraków - Ząbki 1999. 
dar i odblask Boga, który jest życiem"15. Chrześcijaństwo stoi na straży godności każdego życia, nawet jeśli jest ono naznaczone cierpieniem. Także w takiej sytuacji życie człowieka pozostaje „,darem Bożym”, który „otwiera nowe możliwości bytu i sensu"16. Niezależnie od trudnych i niesprzyjających okoliczności, „gdziekolwiek jest życie, pozostaje ono zawsze darem Bożym, a zarazem zadaniem dla współżyjących”, bo domaga się „od nich służebnej miłości, czyni ich samych bogatszymi i wolniejszymi" "17. Św. Augustyn przywołuje w swoich Wyznaniach słowa psalmu: „Pan nasz jest wielki i zasobny w siły, mądrość Jego jest niewypowiedziana" (Ps 147,5). Następnie, zwracając się do Boga, tłumaczy, że właśnie z tego powodu „chwalić Cię chce człowiek, drobna cząstka stworzenia Twojego" i pomimo swojej słabości i grzeszności „chce Ciebie, bo jest drobną cząstką stworzenia Twojego” i „Ty go pobudzasz, że mu chwalić Ciebie przyjemnie, bo stworzyłeś nas dla siebie i niespokojne jest serce nasze: aż nie spocznie w Tobie" ${ }^{18}$.

W języku potocznym, dla podkreślenia sprawiedliwości jakiegoś człowieka mówi się: „on jest Bogu ducha winien”. Jest to o tyle poprawne stwierdzenie, że to Bóg daje człowiekowi duszę i życie. Bóg daje jednak też i ciało. W tym kontekście K. Wojtyła w dziele Miłość i odpowiedzialność zgłasza postulat, aby zachować „sprawiedliwość względem Boga”19. Wyjaśnia, że owa sprawiedliwość wymaga zachowania „porządku natury”, a także uwydatnienia „wartości osoby”" ${ }^{20}$. Jest on zdania, że „wartość osoby stworzonej (tj. stworzenia, które jest osobą) uwydatnia się najpełniej przez uczestnictwo w myśli Stwórcy"21. Gdy osoba stworzona swoim myśleniem i działaniem wypełnia wolę Boga, okazuje miłość Jemu, a przez Niego także stworzeniom. Z drugiej strony, zachowanie stworzonego ,porządku natury” jest nie tylko wyrazem szacunku dla stworzeń, ale też miłości wobec ich Stwórcy. Wszystkie przecież od Niego pochodzą i do Niego należą.

Stwórca jest Ojcem stworzenia, bo ,jest pierwszym początkiem wszystkiego i transcendentnym autorytetem” oraz „równocześnie jest dobrocią i miłującą troską obejmującą wszystkie swoje dzieci"”22. Człowiek mógł poznać Boże ojcostwo dzięki wcieleniu i ziemskiemu życiu Bożego Syna. Od Ewangelii o Ojcu należy przejść do Dobrej Nowiny o roli Syna w stworzeniu człowieka i jego egzystencji.

\footnotetext{
${ }^{15}$ J. Ratzinger, Śmierć i życie wieczne, tłum. M. Węcławski, Warszawa 1986, s. 98.

${ }^{16}$ Tamże.

${ }^{17}$ Tamże.

${ }^{18}$ Augustyn, Wyznania, 1, 1, tłum. M.B. Szyszko, Kielce 2008.

${ }^{19}$ K. Wojtyła, Miłość $i$ odpowiedzialność, red. T. Styczeń i in., Lublin 2001, s. 220. Więcej na temat sprawiedliwości wobec Stwórcy zob. tamże, s. 219-223.

${ }^{20}$ Tamże, s. 221.

${ }^{21}$ Tamże.

${ }^{22}$ Katechizm Kościoła Katolickiego, nr 239.
} 


\section{EWANGELIA O LOGOSIE I JEGO WCIELENIU. PRZYCZYNA, SENS I CEL ISTNIENIA}

Są dzieci, które wiedzą, że żyją za cenę życia swej matki. Urodziły się, bo ona poświęciła swoje życie. Ktoś umarł, aby ktoś mógł żyć. Brak wewnętrznej zgody na przyjęcie daru życia za cenę życia matki musi zaowocować brakiem pojednania z samym sobą, z faktem własnego istnienia. Wówczas dziecko żyje, ale jedynie w cieniu własnego życia.

Rodzice przekazują życie dzieciom. Źródłem życia jest jednak jedynie sam Bóg. Stwórca dał życie człowiekowi, ale także w Chrystusie oddał własne życie za człowieka. W tym kontekście należy rozumieć, dlaczego dzieło odkupienia jest nazywane też nowym stworzeniem. Bóg stwarza człowieka, dając mu życie, a dzięki wcieleniu Bóg mógł również na nowo stworzyć człowieka, oddając za niego swoje życie (por. Mt 20,28; J 10,17-18; 17,19).

W świetle nowego stworzenia człowiek widzi więcej na temat pierwszego. Dostrzega, że jego Stwórcą jest Ojciec, Syn i Duch Święty, że istnieje z miłości będącej wewnętrzna atmosferą wspólnoty Osób Boskich. Prorocy nie mogli tego objawić narodowi wybranemu. Dopiero sam Ojciec przez swego Syna, zapowiadanego przez nich, którego „ustanowił dziedzicem wszystkich rzeczy” i przez którego „stworzył wszechświat” (Hbr 1,2), objawione zostały „,rzeczy ukryte od założenia świata” (Mt 13,35). Syn przyszedł objawić człowiekowi swego Ojca. Tylko On mógł tego dokonać, gdyż ,jest odblaskiem Jego chwały i odbiciem Jego istoty" (Hbr 1,3). Św. Paweł nazywa Chrystusa „obrazem Boga niewidzialnego - Pierworodnym wobec każdego stworzenia, bo w Nim zostało wszystko stworzone: i to, co w niebiosach, i to, co na ziemi, byty widzialne i niewidzialne” (Kol 1,15-16). W Chrystusie „mieszka cała Pełnia: Bóstwo, na sposób ciała" (Kol 2,9; por. Kol 1,19). W Modlitwie arcykapłańskiej Chrystus zwraca się do Ojca: „Ojcze, chcę, aby także ci, których Mi dałeś, byli ze Mną tam, gdzie Ja jestem, aby widzieli chwałę moją, którą Mi dałeś, bo umiłowałeś Mnie przed założeniem świata" (J 17,24).

Dzieło nowego stworzenia jest odwiecznie zamierzone i poniekąd już obecne w pierwszym. Św. Paweł stwierdza, że Ojciec w swoim Synu „wybrał nas przez założeniem świata, abyśmy byli święci i nieskalani przed Jego obliczem” (Ef 1,4). Przez Jezusa Chrystusa Bóg ,przeznaczył nas dla siebie jako przybranych synów" (Ef 1,5).

Doniosłe znaczenie dla teologii stworzenia ma paralela Adam - Chrystus $^{23}$. „Stał się pierwszy człowiek, Adam, duszą żyjącą, a ostatni Adam duchem ożywiającym” (1 Kor 15,45). O pełni bytu „pierwszego" stanowi odkupieńcze dzieło „Ostatniego Adama”24. Sobór Watykański II stwierdza bowiem,

\footnotetext{
${ }^{23}$ Por. V. Croce, Gesù il Figlio e il mistero della croce. Cristologia e Soteriologia, Leumann 2010, s. 293-297: „Cristo il vero Adamo”.

${ }^{24}$ „Tradycja lokalizująca Kalwarię na obecnie znanym miejscu sięga czasów św. Heleny, a nawet pierwszych generacji chrześcijańskich. Nazwa Golgota (hebr. gulgoleth, aram.

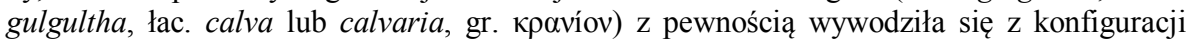


iż „tajemnica człowieka wyjaśnia się naprawdę dopiero w tajemnicy Słowa Wcielonego" 25 . Chrystus mówi o sobie, że jest „Alfą i Omegą, Pierwszym i Ostatnim, Początkiem i Końcem” (Ap 22,13). Właśnie jako taki jest lekarstwem na wszelkie dolegliwości ludzkiej natury, gdyż ,jak w Adamie wszyscy umierają, tak też w Chrystusie wszyscy będą ożywieni” (1 Kor 15,22) ${ }^{26}$. Chrystus wyznacza więc poziom człowieka spełnionego. Z drugiej strony jest On także szczególnie obecny na „początku” zaistnienia człowieka. Właśnie z tego powodu „Ojcowie Kościoła mówią, że gdy [Bóg] stwarzał człowieka «na swój obraz», najpierw spojrzał na Chrystusa i stworzył człowieka wedle obrazu «Nowego Adama» - Człowieka wzorcowego"27. Ma to ogromne znaczenia dla teologicznej refleksji antropologicznej, gdyż dla chrześcijan Chrystus jest nie tylko wzorem dobrego życia, ale także Zasada bycia człowiekiem: dzieckiem Boga i Jego obrazem.

\section{EWANGELIA O DUCHU, DAWCY ŻYCIA. SPOSÓB ISTNIENIA I ROZWOJU}

Od momentu wcielenia Chrystusa Jego odkupieńczej misji towarzyszy Duch Święty. Św. Paweł napisał, że gdy „,nadeszła pełnia czasu, zesłał Bóg Syna swego, zrodzonego z niewiasty, zrodzonego pod Prawem, aby wykupił tych, którzy podlegali Prawu, abyśmy mogli otrzymać przybrane synostwo. Na dowód tego, że jesteście synami, Bóg wysłał do serc naszych Ducha Syna swego, który woła: Abba, Ojcze!" (Ga 4,4-6). W nazaretańskiej synagodze Jezus odczytuje słowa z księgi proroka Izajasza: „Duch Pański spoczywa na Mnie, ponieważ Mnie namaścił i posłał Mnie, abym ubogim niósł dobrą nowinę, więźniom głosił wolność, a niewidomym przejrzenie; abym uciśnionych odsyłał wolnymi, abym obwoływał rok łaski od Pana" (Łk 4,18-19; por. Iz 61,1-2). Jego mesjańska misja żyje Duchem Świętym, jest przeniknięta bowiem miłością samego Boga. Gdy Jezus naucza, uzdrawia, wskrzesza, wyrzuca złe duchy, głosi nadejście królestwa Bożego, wzywa do nawrócenia, to jednocześnie „przywraca ludzkości Boże Ojcostwo” i „przywraca też ludzkość Ojco-

terenu - było to wzgórze przypominające czaszkę, wzniesione ok. $5 \mathrm{~m}$ ponad poziom otaczającego je terenu. Wg legendy podanej przez Orygenesa była tu pogrzebana czaszka Adama i stąd miała się wywodzić nazwa wzgórza" (E. Szymanek, Wyktad Pisma Świętego Nowego Testamentu, Poznań 1990, s. 188). Św. Hieronim nie potwierdza tej interpretacji.

${ }^{25}$ Sobór Watykański II, Konstytucja duszpasterska o Kościele w świecie wspótczesnym ,Gaudium et spes”, nr 22.

${ }^{26}$ Warto zwrócić uwagę na głęboką analizę hymnu chrystologicznego z Kol 1,15-20 (por. M. Kehl, I widziat Bóg, że to jest dobre. Teologia stworzenia, thum. W. Szymona, Poznań 2008, s. 202-205). Autor prowadzi rozważania wokół trzech tematów: „stworzenie w Chrystusie”, „stworzone przez Chrystusa” oraz „stworzone dla Chrystusa”. Por. także: H. Langkammer, Kol 1,15-20. Dzieło dwóch różnych autorów, „Roczniki TeologicznoKanoniczne" 1970, t. 17, z. 1, s. 61-101.

${ }^{27} \mathrm{~J}$. Ratzinger - Benedykt XVI, Jezus z Nazaretu. Od chrztu w Jordanie do przemienienia, cz. I, tłum. W. Szymona, Kraków 2007, s. 123. 
stwu Boga"28. Duch Święty jest także obecny w tych szczególnych momentach życia Jezusa, w których jawi się On w swej relacji do Ojca ${ }^{29}$.

Wreszcie przed swoją męką i śmiercią Jezus zapowiada apostołom, że „pożyteczne jest dla nich Jego odejście. Bo jeżeli nie odejdzie, Pocieszyciel nie przyjdzie do nich. A jeżeli odejdzie, pośle Go do nich" (por. J 16,7). Zatem związane z „odejściem” Chrystusa „przyjście” czy „posłanie” Ducha Świętego należy postrzegać jako „nowy początek $w$ odniesieniu do pierwszego i pierwotnego zarazem początku zbawczego udzielania się Boga, który łączy się z samą tajemnicą stworzenia" ${ }^{30}$. Już w pierwszych słowach Pisma Świętego znajduje się stwierdzenie: „Na początku Bóg stworzył niebo i ziemię. Ziemia zaś była bezładem i pustkowiem: ciemność była nad powierzchnią bezmiaru wód, a Duch Boży unosił się nad wodami” (Rdz 1,1-2). Jan Paweł II podkreśla, że ,to biblijne pojęcie stworzenia oznacza nie tylko powołanie do istnienia samego bytu wszechświata: czyli obdarowanie istnieniem - oznacza ono również obecność Ducha Bożego w stworzeniu: czyli początek zbawczego udzielania się Boga temu, co stworzył”31. W człowieku owo „udzielanie się Boga” dotknie najgłębszego poziomu.

Znamienne, że „Chrystus łączy nowy początek zbawczego udzielania się Boga w Duchu Świętym z tajemnicą Odkupienia”32. Istota „nowości” tego „początku” jest związana z faktem grzechu, który zaległ „pomiędzy pierwszym początkiem, a całymi dziejami człowieka - począwszy od pierworodnego upadku" 33 . Grzech z istoty swojej jest ,przeciwieństwem obecności Ducha Bożego w stworzeniu, nade wszystko zaś przeciwieństwem zbawczego udzielania się Boga człowiekowi" "34. Ten bowiem jest obrazem Boga i na wzór Chrystusa jest „powołany do życia Duchem” (1 P 3,18).

${ }^{28}$ Jan Paweł II, „Czy wolno lekkomyślnie narażać polskie rodziny na dalsze zniszczenie?". Homilia wygłoszona podczas Mszy św. na lotnisku w Mastowie (Kielce), nr 5, „L'Osservatore Romano” (wyd. pol.) 5(1991), s. 31.

${ }^{29}$ Por. Łk 3,21-22: „Kiedy cały lud przystępował do chrztu, Jezus także przyjął chrzest. A gdy się modlił, otworzyło się niebo i Duch Święty zstąpił na Niego, w postaci cielesnej niby gołębica, a z nieba odezwał się głos: «Tyś jest mój Syn umiłowany, w Tobie mam upodobanie»" (por. także: Mt 3,13-17; Mk 1,9-11; J 1,32-34 oraz relacje o przemienieniu Pańskim: Mt 17,1-8; Mk 9,2-8; Łk 9,28-36). Benedykt XVI przypomina, że „w całości przekazu zwiastowania (Łk 1,26-38) daje się jednocześnie słyszeć aluzja do tajemnicy Boga Trójjedynego" (J. Ratzinger - Benedykt XVI, Jezus z Nazaretu. Dzieciństwo, thum. W. Szymona, Kraków 2012, s. 45).

${ }^{30}$ Jan Paweł II, Encyklika „Dominum et Vivificantem”, nr 12.

${ }^{31}$ Tamże.

${ }^{32}$ Tamże, nr 13.

${ }^{33}$ Tamże.

${ }^{34}$ Tamże. „Napisze św. Paweł, że właśnie na skutek grzechu «stworzenie... zostało poddane marności..., aż dotąd jęczy i wzdycha w bólach rodzenia...»-i «z upragnieniem oczekuje objawienia się synów Bożych» (Rz 8,19-22)" (tamże). 


\section{EWANGELIA O ODKUPIENIU. NOWE STWORZENIE W WOLNOŚCI JUŻ NIE TYLKO BOGA}

Już w trzecim rozdziale Księgi Rodzaju jest mowa o odkupieniu (por. $3,15)$. Nieco później poprzez postać Abrahama Bóg objawia się jako Ojciec, który wyda swego Syna na ofiarę za grzechy ludzkości (por. Rdz 22,8-18) ${ }^{35}$.

Grzech Adama dokonany w „czasach ponadhistorycznych”, o których mówią nam pierwsze rozdziały Księgi Rodzaju, wprowadził pewną dysharmonię w relację człowieka do Boga. Człowiek zdradził swego Stwórcę brakiem posłuszeństwa. Tym samym sam ściągnął na siebie winę i lęk (por. $\mathrm{Rdz}$ 3,8-10). Misja Chrystusa polegała na przywróceniu rodzinie ludzkiej „Ojcostwo Boga”, przy czym „tylko On jeden mógł tego dokonać w sposób pełny”36. Dla wypełnienia tej misji Odkupiciel musiał „przywrócić ludzi Bogu jako Ojcu"37. Oczywiście, nie dokonało się to „przez samo nauczanie”, lecz ostatecznie „dopiero przez krzyż" ${ }^{38}$. Krzyż Chrystusa jest symbolem miłości do Ojca i posłuszeństwa wobec Jego woli. Syn Boży ma świadomość, że przyszedł na świat nie „sam od siebie” (J 7,28), lecz „w imieniu Ojca” (J 5,43). Dlatego właśnie „uniżył samego siebie, stawszy się posłusznym aż do śmierci - i to śmierci krzyżowej" (Flp 2,8). W Chrystusie dopełniają się słowa Apostoła Pawła, który stwierdził, że ,jak przez nieposłuszeństwo jednego człowieka wszyscy stali się grzesznikami, tak przez posłuszeństwo Jednego wszyscy staną się sprawiedliwymi” (Rz 5,19).

Św. Paweł w charakterystyczny dla siebie sposób „tłumaczy tajemnicę grzechu pierworodnego" ${ }^{\text {"3 }}$. Zdaniem Apostoła Narodów grzech ten jest odrzuceniem Bożego Ojcostwa. Odrzucenie to „zaciążyło na całych dziejach człowieka od początku" "40. Lektura trzeciego rozdział pierwszej księgi Pisma Świętego pozwala dostrzec, iż wspomniane przez apostoła w Liście do Rzymian ,pierworodne «nieposłuszeństwo» jest właśnie odrzuceniem Ojcostwa Boga"41. Jego naprawa dokonała się mocą posłuszeństwa Bożego Syna, Wcielonego Słowa, Ojca. Z jednej strony „odkupieńczy czyn Syna współistotnego Ojcu przywraca ludzkości Boże Ojcostwo"42. Z drugiej zaś czyn ten „przywraca też ludzkość Ojcostwu Boga w Jednorodzonym Jego Synu”33. Zatem w Chrystusie, Odkupicielu świata, „Pierworodnym spośród umarłych” (Kol 1,18), można dostrzec „obecny już teraz Prasakrament, Pra-

\footnotetext{
${ }^{35}$ Por. tenże, Rozmowa ojca z synem w krainie Moria, w: Tryptyk rzymski. Medytacje, Kraków 2003, s. 34-36.

${ }^{36}$ Tenże, ,Czy wolno lekkomyślnie narażać polskie rodziny na dalsze zniszczenie?”, nr 4, dz. cyt., s. 31 .

${ }^{37}$ Tamże.

${ }^{38}$ Tamże.

${ }^{39}$ Tamże.

${ }^{40}$ Tamże.

${ }^{41}$ Tamże, nr 5, s. 31.

${ }^{42}$ Tamże.

${ }^{43}$ Tamże.
} 
wzór, Ikonę [...] definitywnego pojednania Stwórcy ze stworzeniem»"44, Ojca i źródła wszelkiego ojcostwa (por. Ef 3,14-15) ze swoimi dziećmi.

\section{EWANGELIA O CZŁOWIEKU WOLNYM. ISTNIEJĄCY NIE Z SIEBIE, NA SPOSÓB DARU}

U podstaw antropologii chrześcijańskiej leży objawienie prawdy, że człowiek jest obrazem i podobieństwem Boga (por. Rdz 1,26-27). Jednocześnie jest ,jedynym na ziemi stworzeniem, którego Bóg chciał dla niego samego”, dlatego „nie może odnaleźć się w pełni inaczej, jak tylko poprzez bezinteresowny dar z siebie samego" "45. Swoją głębią życia duchowego, jak i godnością ciała będącego „świątynią Ducha” (1 Kor 6,19), człowiek przekracza horyzont świata widzialnego. Jest jego częścią, podlega prawom biologii i fizyki, jednak nie daje się ograniczyć do tego, co jedynie widzialne. Słusznie więc pyta psalmista: „czym jest człowiek, że o nim pamiętasz, i czym - syn człowieczy, że się nim zajmujesz?" (Ps 8,5).

Dlaczego człowiek został stworzony? Dość jasno i prosto odpowiada na to pytanie św. Ireneusz, stwierdzając, że stworzenie przez Boga Adama dokonało się nie z powodu jakiegoś braku doświadczanego przez Stwórcę, „lecz by miał kogoś, komu mógłby udzielić swoich darów" "46. Ireneusz thumaczy, że „nie tylko przed stworzeniem Adama, ale zanim jeszcze cokolwiek zaczęło istnieć, Słowo już wielbiło Ojca, trwając w Nim, i samo doznawało chwały od Ojca"47. Jako potwierdzenie tej opinii podaje on słowa modlitwy Chrystusa: „A teraz Ty, Ojcze, otocz Mnie u siebie tą chwałą, którą miałem u Ciebie pierwej, zanim świat powstał" (J 17,5). Akt stwórczy jest całkowicie wolny. Wszystko, co istnieje, nie jest wynikiem konieczności, lecz miłości Boga. Człowiek jako arcydzieło Bożych rąk ${ }^{48}$ jest godny wielkiego podziwu. Mimo to nie przysługuje mu chwała należna Bogu. Człowiek nie jest Bogiem, jednak, aby być tym, kim jest, potrzebuje Boga jako źródła swej siły i celu swych dążeń.

Świadomość bycia stworzonym winna człowieka wciąż uwrażliwiać na prawdę, iż świat bez Boga jest nieludzki, tak samo jak człowiek bez Chrystusa nie jest w pełni sobą i żyje jedynie w cieniu wielkiej sprawy człowieka. Stworzenie człowieka rozumnym, wolnym i zdolnym do złożenia „daru z siebie" jest wyraźnym objawieniem wielkości Boga, ale objawienie ma także moc stwórczą: człowiek przyjmujący je, dając, się przeniknąć jego treścią, tworzy się od wewnątrz. W stworzeniu świata Bóg przekroczył gra-

${ }^{44}$ M. Kehl, I widziat Bóg, że to jest dobre. Teologia stworzenia, thum. W. Szymona, Poznań 2008, s. 205.

${ }^{45}$ Sobór Watykański II, Konstytucja duszpasterska o Kościele w świecie wspótczesnym ,, Gaudium et spes”, $\mathrm{nr} 24$.

${ }^{46}$ Ireneusz z Lyonu, Przeciw herezjom, 4; cyt. za: Liturgia Godzin. Codzienna modlitwa Ludu Bożego, t. II, Poznań 1984, s. 65.

${ }^{47}$ Tamże.

${ }^{48}$ Psalmista stwierdza to wprost: „Twe ręce mnie uczyniły i ukształtowały” (Ps 119,73). 
nicę między nicością a bytem niebędącym Bytem Absolutnym. W stworzeniu człowieka przekroczył granicę między materią a duchem. We wcieleniu natomiast przekroczył granicę między tym, co Boskie, a tym, co ludzkie. W zmartwychwstaniu przekroczył próg życia i śmierci, cierpienia i zdrowia, porażki i wygranej, zbrodni i sprawiedliwości. Człowiekiem, w którym najowocniej działa łaska Stwórcy, jest Maryja, Matka Pana. Jej życie i wybory idealnie korespondują z planami Boga dla Jej osoby, a przez to także dla całej ludzkości.

Skoro człowiek jest obrazem Boga, to właśnie ten fakt stanowi mocny fundament teologicznego zainteresowania się osobą ludzką. Teolog musi mieć głęboką świadomość, że „ucieczka od człowieka nie jest wędrówką w stronę Boga"49. Wcielenie Syna Bożego sprawia, że sprawy Boże już w stworzeniu stają się poniekąd sprawami człowieka, a „negacja Boga nie jest powiększeniem przestrzeni wolności człowieczeństwa"s0, lecz jedynie pierwszym krokiem w stronę degradacji człowieka i postawienia go w stan oskarżenia przed sobą samym.

\section{EWANGELIA O WIECZNOŚCI. SPELNIENIE ISTNIENIA PRZYGODNEGO}

Człowiek urodził się, aby pójść do nieba. Potrzebuje on istnieć, potrzebuje być, aby móc w nim się znaleźć. To pierwszy, choć nie jedyny warunek. Wolność bowiem, która przysługuje z natury ludzkiemu jestestwu, domaga się akceptacji tego daru, zgody na to zaproszenie ze strony Stwórcy. Stworzenie ludzkiej osoby jest zaproszeniem jej ze strony Boga do wędrówki wiary poprzez pracę (por. Rdz 1,28) i odkrywanie swego nadprzyrodzonego przeznaczenia. Już w stworzeniu Adama (poniekąd nawet całego świata, choć na innym poziomie; por. Rz 8,20) widoczne jest ukierunkowanie na wieczność. Byt człowieka, jego wewnętrzna głębia, moralność i nagroda, implikują konieczność istnienia po śmierci. Został on tak stworzony, że wykracza poza świat materialny. Chrystus ostrzega: „Nie bójcie się tych, którzy zabijają ciało, a potem nic więcej uczynić nie mogą. [...] Bójcie się Tego, który po zabiciu ma moc wtrącić do piekła" (Łk 12,4-5). Ludzka egzystencja dopiero w wieczności odnajdzie pełnię swej realizacji, gdyż ojczyzna człowieka jest w niebie (por. Flp 3,20).

W oknie eschatologicznej rzeczywistości można dostrzec pełniejsze znaczenie zła i jego związek z dziełem stworzenia. Już na wstępie trzeba podkreślić, że ,zło nie jest jeszcze jednym owocem stworzenia, nie jest czymś rzeczywistym, czymś, co by istniało samo w sobie, lecz ze swej istoty

${ }^{49}$ Por. J. Szymik, W światłach Wcielenia. Chrystologia kultury, Katowice - Ząbki 2004, s. 104.

50 Tamże. 
pozostaje negacją, która pożera owoc stworzenia"51. Skąd więc zło? Pochodzi ono $\mathrm{z}$ wolności bytów rozumnych i wolnych: najpierw diabła i jego aniołów, a następnie także człowieka ${ }^{52}$. Teologia stworzenia i eschatologia utrzymują, że ,zło nie jest ani podstawowe, ani ostateczne" ${ }^{\text {53 }}$. Całe stworzenie jest bowiem „bardzo dobre” (Rdz 1,31), a zło i grzech są wtóre wobec aktu stwórczego. $Z$ drugiej zaś strony ,potęga Chrystusowego krzyża i zmartwychwstania jest zawsze większa od wszelkiego zła, którego człowiek może i powinien się lękać” ${ }^{4}$. Jan Paweł II dopowiada nawet, że „poprzez swoje zmartwychwstanie Chrystus poniekąd «usprawiedliwił» dzieło stworzenia, a szczególnie stworzenia człowieka" ${ }^{55}$. Zdaniem Papieża owo „usprawiedliwienie” polegało na objawieniu przez Odkupiciela ,właściwej miary” dobra,

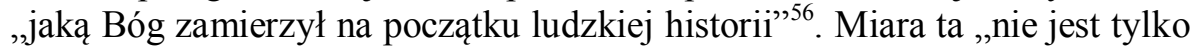
tą przewidzianą przez Niego [Boga] w akcie stworzenia, a potem zniweczoną przez grzech człowieka", ale ,,jest to miara nadobfita, w której pierwotny zamysł realizuje się jeszcze pełniej (por. Rdz 3,14-15)",57. Chrystus przekazał człowiekowi zaproszenie „,do nowego życia - życia syna w Synu, które doskonale wyraża chwałę Boga" ${ }^{\text {"5 }}$. Syn Boży przyszedł człowieka obdarować swoim Synostwem, aby uczynić go na nowo i jeszcze pełniej synem Bożym.

$\mathrm{Z}$ tym wiąże się także temat Bożej Opatrzności. Bł. Jan Paweł II, komentując 1 P 1,3-4.6-7 $7^{59}$, naucza w swojej katechezie, że „prawda objawiona o «przeznaczeniu», jakie świat stworzony, a nade wszystko człowiek ma w Chrystusie (praedestinatio in Christo), stanowi ostateczną i nieodzowną podstawę rozważań na temat stosunku, jaki zachodzi pomiędzy Opatrznością Bożą a rzeczywistością zła w świecie, w szczególności zaś cierpienia" ${ }^{60}$. Jak niesprawiedliwy sąd i wyrok na Chrystusa ukazują realność zła i zagrożeń dobra oraz innych wartości ludzkiej egzystencji, tak Jego zmartwychwstanie i wniebowstąpienie ukazują, że człowiek jest „w ręku Boga” (por. Mdr 3,1), a do Boga należy ostatnie słowo (por. Dz 2,24).

${ }^{51} \mathrm{~J}$. Ratzinger, Bóg $i$ świat. Wiara i życie $w$ dzisiejszych czasach. Z kardynatem Josephem Ratzingerem (Benedyktem XVI) rozmawia Peter Seewald, tłum. G. Sowinski, Kraków 2005, s. 117.

${ }_{52}$ Por. tamże. Por. także: Rdz 3,4-5; Mdr 2,24 oraz Rdz 2,17.

${ }^{53}$ Jan Paweł II, Przekroczyć próg nadziei. Jan Pawel II odpowiada na pytania Vittoria Messoriego, wyd. III, Lublin 2005, s. 37.

${ }^{54}$ Tamże, s. 170.

${ }^{55}$ Tenże, Pamięć i tożsamość. Rozmowy na przełomie tysiącleci, Kraków 2005, s. 32.

${ }^{56}$ Tamże.

${ }^{57}$ Tamże.

${ }^{58}$ Tamże.

59 „Niech będzie błogosławiony Bóg i Ojciec Pana naszego Jezusa Chrystusa. On w swoim wielkim miłosierdziu przez powstanie z martwych Jezusa Chrystusa na nowo zrodził nas do żywej nadziei: do dziedzictwa niezniszczalnego i niepokalanego, i niewiędnącego, które jest zachowane dla was w niebie. [...] Dlatego radujcie się, choć teraz musicie doznać trochę smutku z powodu różnorodnych doświadczeń. Przez to wartość waszej wiary okaże się o wiele cenniejsza od zniszczalnego złota, które przecież próbuje się w ogniu" (1 P 1,3-4.6-7).

${ }^{60}$ Jan Paweł II, Opatrzność Boża a obecność zła i cierpienia $w$ świecie, nr 1, w: tenże, Katechezy Ojca Świętego Jana Pawła II. Bóg Ojciec, Kraków - Ząbki 1999. 


\section{ZAKOŃCZENIE}

Cała teologia chrześcijańska przeniknięta jest logika stworzenia. Jest to logika daru, sensu i miłości. Ukazała to powyższa analiza wybranych aspektów teologicznych. Słusznie zostały ona określone jako Ewangelie, gdyż niosą dla człowieka dobra nowinę o stworzeniu go z miłości i przeznaczeniu do udziału w Jej pełni. Stworzenie człowieka na obraz i podobieństwo Boże jest znaczącym wydarzeniem dla życia Trójjedynego Boga ${ }^{61}$. Nieporozumieniem będzie utrzymywanie, że to Boga pomniejsza albo sprowadza do historii świata stworzonego.

Powołanie człowieka do istnienia okazało się dla świata momentem przełomowym, całkowitym novum. Pan Bóg, stwarzając Adama, „wybrał wszystkich ludzi (por. Dz 17,26)", bo stworzenie ,jest pierwotnym wyborem (z nicości do bytu)"62. Odkupienie dokonane przez "Ostatniego Adama” (por. 1 Kor 15,45 ) potwierdziło ten wybór bardzo konkretnie i stanowczo. Tym samym „Bóg uczynił wszystko, aby człowieka «wybrać» już ostatecznie” do zbawienia, jednak człowiekowi pozostawił decyzję „o jego osobistym udziale i przyjęciu tego «Bożego wyboru» (por. Pwt 30,19-20)",63. Możliwość osobistej decyzji każdego człowieka świadczy o ogromnym zaufaniu Boga do niego oraz o jego wielkiej godności.

Świat stworzeń nierozumnych nie może się wyprzeć swego Stwórcy, w sposób naturalny żyje więc w zgodzie z Jego wolą. Rośliny, zwierzęta, choć nie są zdolne, aby świadomie uczcić swego Stwórcę, żyją jednak ,sprawiedliwie wobec Niego", gdyż egzystują zgodnie ze swoją naturą. Człowiek zaś, jako korona stworzeń, jako król pośród świata widzialnego, sam ma się opowiedzieć, czy Boga przyjmuje jako swego Stwórcę, swego Ojca, czy Go odrzuca. Gdy wybierze drugą opcję, w pewnym sensie wynaturza się. Bez świadomego odniesienia do swego Stwórcy człowiek pozostaje bezpańskim królem.

Stworzenie świadomie przyjęte stawia każdego konkretnego człowieka zawsze w pozycji wybranego, obdarowanego i umiłowanego przez Boga, Stwórcę, Odkupiciela i Dawcę życia. Św. Klemens Rzymski zachęca, aby „będąc uczestnikami licznych i wspaniałych wydarzeń” wracać „ustawicznie do tego pokoju, który nam został przekazany na samym początku, a mając pilnie utkwiony wzrok w Rodzicu i Stwórcy całego świata, przylgnijmy mocno do Jego łaski oraz wzniosłych i przeobfitych darów pokoju"64. Św. Paweł zaś daje przykład zgięcia kolan ,przed Ojcem, od którego bierze nazwę wszelki ród na niebie i na ziemi" (Ef 3,14-15). Czyniąc tak, człowiek nic nie traci ze swej godności, a jedynie doskonali się w człowieczeństwie „według Pełni Chrystusa” (Ef 4,13), Bożego Syna.

${ }^{61}$ Por. Interpretacja słów Stwórcy: „Uczyńmy człowieka na Nasz obraz, podobnego Nam” (Rdz 1,26) (S. Kunka, Bóg Stwórca człowieka, „Roczniki Teologii Dogmatycznej” 2011, t. 3[58], s. 188-193).

${ }^{62}$ Tenże, Teologia wybrania. Kilka myśli na temat wybrania czlowieka przez Boga, „Teologia w Polsce” 1(2011), s. 70.

${ }^{63}$ Tamże.

${ }^{64}$ Klemens Rzymski, List do Koryntian; cyt. za: Liturgia Godzin. Codzienna modlitwa Ludu Bożego, dz. cyt., s. 46. 